\title{
Illustrating Authority: The Creation and Reception of an English Protestant Iconography
}

\author{
Nora Epstein
}

Tudor printer and publisher John Day established his dominance over the trade in English martyrologies and cemented a reputation for brazen Protestant polemics packaged in richly illustrated books with the publication of his 1563 book Actes and Monuments. While much ink has been spent on Day's effective use of paratext and illustrations to further his patrons' propagandistic endeavours, significantly less has been written about his most heavily illustrated texts: Christian Prayers and Meditations (1569) and the subsequent A Booke of Christian Prayers (1st ed. 1578). ${ }^{1}$ While the two prayer books have too many textual and visual variations to be considered two editions of the same work, their shared content and means of creation makes it imprudent to examine them in isolation. ${ }^{2}$ As the most densely illustrated Tudor prayer books, the little attention these works have received in the historiography

1 Christian prayers and meditations in English, French, Italian, Spanish, Greek and Latine (London: John Day, 1569), USTC 39731; A booke of Christian prayers, collected out of the auncient writers, and best learned in our tyme, worthy to be read with an earnest mynde of all Christians, in these daungerous and troublesome dayes, that God for Christes sake will yet still be mercyfull unto us (London: John and Richard Day, 1578), USTC 508554, 509278, 511512, \& 3003447. For Actes and Monuments: see Julian Roberts, 'Bibliographical Aspects of John Foxe', in D.M. Loades (ed.), John Foxe and the English Reformation (Aldershot: Ashgate Scolar Press, 1997) pp. 36-51; Elizabeth Evenden and Thomas S. Freeman, Religion and the Book in Early Modern England (Cambridge: Cambridge University Press, 2011); Elizabeth Evenden and Thomas S. Freeman, 'Print, Profit and Propaganda: The Elizabethan Privy Council and the 1570 Edition of Foxe's “Book of Martyrs", The English Historical Review, 119 (2004), pp. 12881307; and John King, Tudor Books and Readers: Materiality and the Construction of Meaning (Cambridge: Cambridge University Press, 2010).

2 In recognition of their similarities, bibliographers have collectively referred to all five editions of these two books as 'Queen Elizabeth's Prayer Book'. Some speculate that the anonymous compiler of Christian Prayers and Meditations was Queen Elizabeth (or John Foxe). See Erzsébet Stróbl, 'The Queen and Death: An Elizabethan Book of Devotion', in Kinga Földváry and Erzsébet Stróbl (eds.), Early Modern Communi(cati)ons: Studies in Early Modern English Literature and Culture (Newcastle upon Tyne: Cambridge Scholars Publishing, 2012), p. 15; Jennifer Clement, 'The Queen's Voice: Elizabeth I's, Christian Prayers and Meditations', Early Modern Literary Studies, 13:3 (2008), pp. 1-26. For the suggestion that Foxe compiled the work: Francis Douce, Dance of Death (London: W. Pickering, 1833), p. 147. 
characterises them as aberrations and oddities. However, when we contextualize the prayer books within Day's political network and print output, they appear particularly on-brand for this image-conscious book producer. For example, Actes and Monuments' prefatory address, 'Ad doctum lectorem', parallels and contrasts Day's martyrology against the most famous compilation of Catholic saints' lives, Jacobus de Voragine's The Golden Legend, (which author John Foxe attacks as being 'filled with prodigious portents and most empty and utterly vain fictions'). ${ }^{3}$ In the years between bringing to market the first two editions of this financially and politically profitable inversion of Catholic hagiographies, Day briefly turned his attention toward appropriating another lay devotional format: books of hours.

The most immediately noticeable feature of Day's two prayer books is their remarkable similarity to printed Catholic books of hours. Both textually and paratextually, the works clearly borrow from early-fifteenth-century private devotional aids, particularly those printed in Paris. Day's choice to assume the conventions of books of hours has led some scholars to position the works as Protestant didactics, masquerading in a comforting Catholic format in an attempt to appeal to popular pre-Reformation sensibilities. Eamon Duffy best expressed this sentiment when he claimed the 1578 book was 'in fact a Trojan Horse, harnessing the old forms to smuggle in the new religion'. ${ }^{4}$ Other scholars have registered surprise at Day's use of a traditional Catholic format. Before unpacking the Protestant text, Richard L. Williams wondered how Day, an 'important figure in the evangelical wing of the English reformers ... [and] printer of John Foxe's Acts and Monuments' could print 'the borders in his 1569 book that were so redolent of books of hours from the time of 'popery' 5 However, when we situate Day's two illustrated prayer books within the context of Actes and Monuments' self-conscious use of the martyrological topos, the prayer books no longer seem surprising.

This chapter will argue that just as Actes and Monuments explicitly positions itself within the Christian literary tradition while inviting comparisons with famous Catholic hagiographies. Day's prayer books similarly employ a distinctive format to draw out a comparison by association. Moreover, the

3 John Foxe, Actes and monuments (London: John Day, [1563]), USTC 506152, sigs. B $3^{\mathrm{r}}-\mathrm{B} 4^{\mathrm{r}}$. Translation from John N. King, 'Literary Aspects of Foxe's Acts and Monuments', The Acts and Monuments Online. [https://www.dhi.ac.uk/foxe/index.php?realm=more\&gototype=\& type=essay\&book=essay12\&anchor=prodigious\#essay12] accessed 9 August 2017.

4 Eamon Duffy, Marking of the Hours: English People and Their Prayers 1240-1570 (New Haven: Yale University Press, 2006), p. 171.

5 Richard L. Williams, 'Censorship and Self-Censorship in Late Sixteenth-century English Book Illustration', in Michael Hunter (ed.), Printed Images in Early Modern Britain (Farnham: Ashgate, 2010), p. 45. 
abundant and shifting illustrations, which caused some scholars to disregard the five editions of these prayer books, are remarkable resources for studying the tensions surrounding religious images in early modern England. Tessa Watt, in her argument against Patrick Collinson's 'iconophobia' thesis, states that a more accurate description of the tightening limitations on religious images is not a sudden change in mentality but 'a continuing process of substituting acceptable images for unacceptable, albeit within increasingly constrictive boundaries'. ${ }^{6}$ The tension Watt describes surrounding the ever-narrowing boundaries of image permissibility is palpable on the pages of Day's prayer books. Rather than deceiving the viewer into unwittingly digesting Protestant theology, they are unique examples of vigorously Protestant prayer books that, like their Catholic model, provided their readers with a rich compendium of iconography.

\section{Patrons on the Page}

Day was careful in his selection of images to print in these deluxe prayer books (as will be detailed below) but the choice of lay Catholic devotional format to refashion for the new church was obvious. For centuries, books of hours fostered a unique relationship between reader and text as practical aids to a spiritual necessity. Additionally, books of hours' established use and traditionally flexible content made them ideal vehicles for disseminating new beliefs while also suggesting historic continuity. Some of the English Reformation's earliest legislation acknowledged the influence of private devotional texts, and sought to control their contents. ${ }^{7}$ Each of the post-Reformation Tudor monarchs, including Catholic Queen Mary, endorsed books of hours that supported their agenda and used devotional aids within their wider propaganda campaigns. ${ }^{8}$ Unlike the many official or quasi-official English Protestant books of hours, Christian Prayers and Meditations did not simply adapt the texts of its Catholic predecessors: the 1569 book was the first to incorporate the abundant illustrative content found in many Catholic works.

6 Tessa Watt, Cheap Print and Popular Piety (Cambridge: Cambridge University Press, 1993), p. 135; Patrick Collinson, From Iconoclasm to Iconophobia (Reading: University of Reading, 1986).

7 Charles C. Butterworth, The English Primers (1529-1545): Their Publication and Connection with the English Bible and the Reformation in England (Philadelphia: University of Pennsylvania Press, 1953); Duffy, Marking the Hours, p. 147-170.

8 Helen C. White, Tudor Books of Private Devotion (Madison: University of Wisconsin Press, 1951); Duffy, Marking of the Hours. 
The visual scheme of the earlier book, Christian Prayers and Meditations, is expressed in elaborated borders that frame the devotions (see figure 16.1). Each border is composed of five cuts, the most prominent of which are the sidepieces closest to the finished book's fore-edge. These sidepieces repeat two highly conventional cycles frequently used in books of hours (or 'primers', as they were often called in England): the Life of Christ and the Dance of Death. In the Life of Christ cycle (repeated seven times in the work) each image associated with an event in Jesus' life is contextualised with a corresponding scriptural quotation and two depictions of Old Testament prefigurations. At the foot of the page are two patriarchs, who indicate to the reader the biblical source for the Old Testament prefigurations. Towards the end of the book, the Life of Christ cycle is replaced with a series of Dance of Death images, which depict the certainty of death by illustrating Death seizing various members of sixteenth-century society in descending order of rank. ${ }^{9}$

Nine years after the publication of Christian Prayers and Meditations, John Day's son Richard reused most of its illustrations in A Booke of Christian Prayers. Like its predecessor, A Booke of Christian Prayers is also a collection of devotions and images based on traditional books of hours. However, fresh from his disappointing work on the much-maligned third edition of Actes and Monuments, Richard exercised his Eton and Cambridge education by expanding the devotional content and framing his prayer book in a signed letter 'To the Christian Reader'.10 Richard also set the work apart from the earlier Christian Prayers and Meditations by diversifying the illustrative content. The 1578 first edition of $A$ Booke of Christian Prayers had four new border cycles: the Virtues, the Six Works of Mercy, the Five Senses and the Fifteen Tokens of Judgement, each with matching footpieces.

Given the religious and political environment of Elizabethan England, lay prayer books are valuable resources for exploring the long process of establishing new orthodoxy and of how contemporaries internalised the state-mandated faith. Day's richly illustrated prayer books were too expensive to have been intended for a large, popular audience, as the three shillings and

9 Douce, Dance of Death, pp. 147-148; Samuel C. Chew, "The Iconography of "A Book of Christian Prayers" (1578), illustrated', Huntington Library Quarterly, 3 (1945), pp. 297-301.

10 White, Tudor Books of Private Devotion, pp. 187-196; Evenden, Patents, Pictures and Patronage, p. 152. Also see William Keating Clay, Private Prayers put Forth by Authority During the Reign of Queen Elizabeth (Cambridge: The Parker Society, 1851). Clay meticulously identifies much of the source material for most of the prayers in A Booke of Christian Prayers. For John and Richard's contentious and litigious relationship, see the above-cited Evenden or C.L. Oastler, 'John Day, the Elizabethan Printer', Oxford Bibliographical Society, 10 (1975), appendix I, pp. 65-69. 


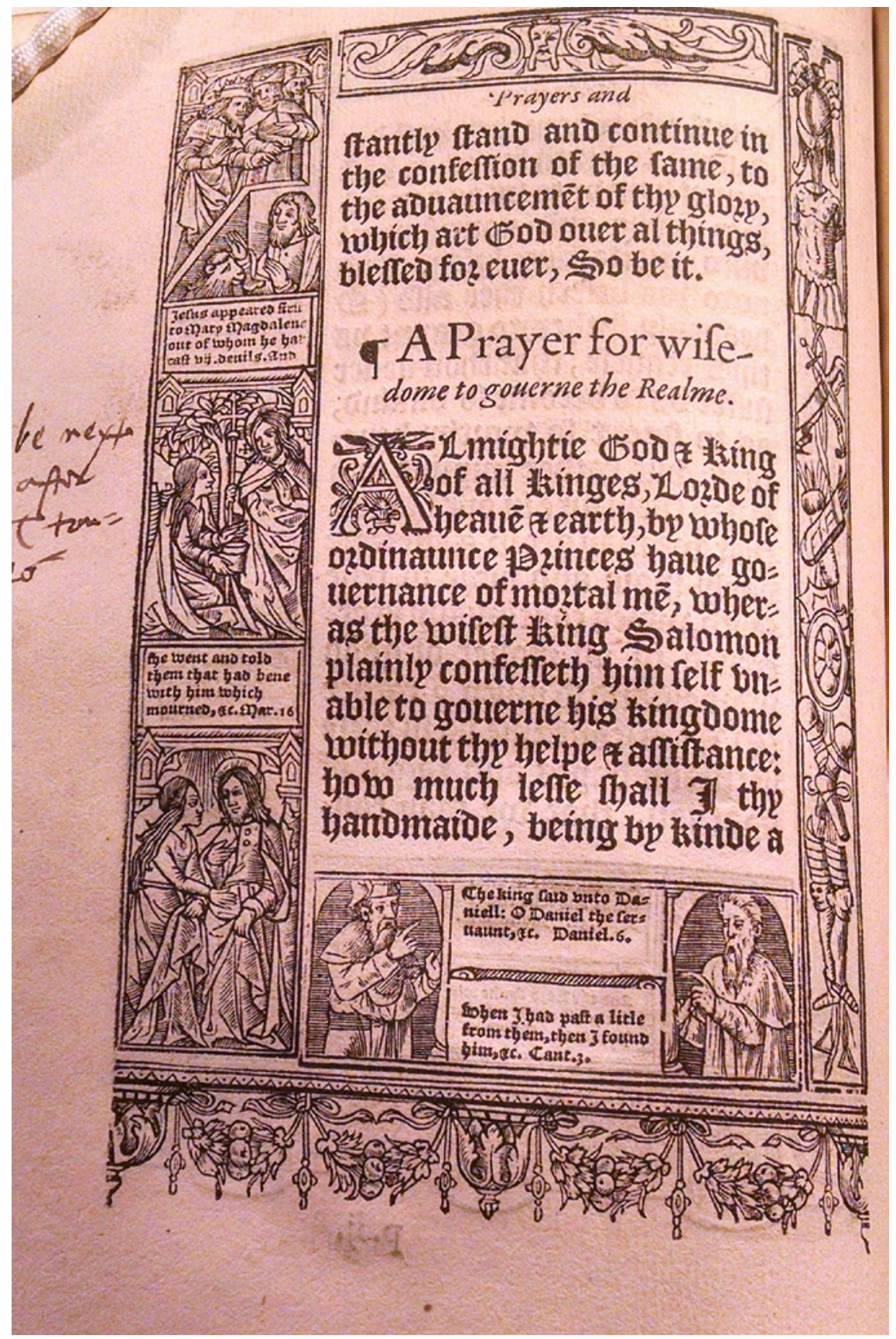

FIG URE 16.1 Christian Prayers and Meditations (1569), $\operatorname{sig} \mathrm{P}_{2} \mathrm{v}$

ST PAUL'S CATHEDRAL LIBRARY 
four pence price that the owner of a copy of $A$ Booke of Christian Prayers (now in Harvard's Houghton Library) paid indicates. ${ }^{11}$ However, the books' official backing, as well as their status as the only luxury printed illustrated prayer books of Elizabethan England, offers rare insight into the political process of establishing a Reformed religious iconography. Like many of Day's deluxe publications, it is likely that he understood the initial return on investment not in terms of success on the retail market, but in how the books bolstered his reputation and relationships. In printing these works, Day appropriated a traditional means of disseminating iconography to establish an English visual vocabulary that suited both the new orthodoxy and his powerful patrons.

Throughout his career, Day was under the patronage of some of the most influential people in English society. As Elizabeth Evenden has shown, Day's long-standing relationships with figures such as William Cecil, Robert Dudley and Archbishop Parker allowed him to secure valuable patents. These included the exclusive rights to publish bestsellers, such as $A B C$ with Little Catechism and the English metrical psalms. ${ }^{12}$ On the many occasions when other members of the Stationers' Company challenged Day's monopolies or ambitions for expansion, his powerful allies often proved crucial in protecting his interests. ${ }^{13}$ Given the often perilous economics of early modern print, satisfying his patrons was essential to Day's success.

11 Houghton Library shelfmark: STC6431, this copy is also available on ЕEво. A 1615 price inscription in another 159 o edition lists a 2 shillings and 1 pence price, National Library of Scotland shelfmark: Gray.449. Among the books included in Francis R. Johnson's often-cited 'Notes on English Retail Book-Prices, 1550-1640', The Library, 5 (1950), pp. 83-112, is an unbound copy of the 1581 edition of $A$ Booke of Christian Prayers. Johnson noted a one-shilling price for Richard Day's book is sourced from the 1585 inventor stock list of Edinburgh bookbinder Robert Gourlaw. Although the price he cites is wholesale, Johnson explains that 'wholesale price in Scotland approximates so closely to the retail price in London' that we can take it as roughly equivalent to the price a Londoner would have paid. By his calculations, the price Johnson lists means that the 1581 A Booke of Christian Prayers sold for .32d a sheet, making it markedly cheaper than the $1.08 \mathrm{~d}$ a sheet the owner of the Harvard copy paid. Tracing this valuation back to Johnson's original source, a 1836 printing of Gourlaw's inventory in The Bannatyne Miscellany, we find that the work he identified as A Booke of Christian Prayers is listed in the inventory simply as 'Cristiane prayeris', which could be a short title for any number of devotional works. It seems clear that Johnson misidentified this work and that his listed price is not accurate.

12 Evenden, Patents, Pictures and Patronage; Andrew Pettegree, 'Day, John (1521/2-1584)', Oxford Dictionary of National Biography (Oxford: Oxford University Press, 2004). Consulted online. [http://www.oxforddnb.com/view/article/7367, accessed 9 Aug., 2017]; Oastler, 'John Day', pp. 22-25.

13 In the case of this book, the records of the Stationers' Company contain a formal challenge against the printing of the 1578 work filed by the son of John Day's former partner, William Seres, on the basis that he had inherited the privilege to print primers from his father. The matter was settled in Day's favour on 28 January 1580 . W.W. Greg and E. Boswell 
Day used his patrons to secure his elevated position in the English print market and the works he produced reinforced those valued relationships. The dedication of Actes and Monuments begins with a woodcut capital C depicting the virgin Queen enthroned atop a vanquished pope and receiving homage from three men, mirroring the iconography of the Adoration of the Magi. ${ }^{14}$ Instead of three kings, the figures in the capital are identified as John Day, John Foxe, and William Cecil. ${ }^{15}$ From the outset Day's intentions are clear, it was the relationship between author, printer and patron that allowed the presentation of this Protestant martyrology to the Queen and her people. In Day's two prayer books, he was not nearly as explicit about the work's patronage, but nevertheless used his text and paratext to please his patrons while expressing the Crown's endorsement of the material within.

As Evenden explains, Day was operating between shifting spheres of influence over his long career and deftly maintained patronage among secular and sacred elites. The only known completed copy of Christian Prayers and Meditations, which now resides in Lambeth Palace Library, is thought to be Elizabeth's presentation copy given to her by Day's patron Archbishop Parker. ${ }^{16}$ Reflecting the status of this gift, this presentation copy was elegantly hand-coloured by artists in Parker's Lambeth workshop. ${ }^{17}$ While Parker undoubtedly played a crucial role in disseminating the 1569 book, it is the Queen's confidant, Robert Dudley Earl of Leicester, whose patronage is most evident within the pages of Day's prayer books. An ornament featuring the heraldic device of Robert Dudley, the staked

(eds.), Records of the Court of the Stationers' Company 1576 to 1602 from Register B (London: Bibliographical Society, 1930), pp. 9-10.

14 This woodcut capital was later used in 1577 on sig. I $3^{\mathrm{r}}$ of John Dee's Perfecte Arte of Navigation (USTC 508331) and in 1578 for Gabriel Harvey's Gratulationum Valdinensium Libri Quatuor (USTC 508571). Roy Strong posits the image of Elizabeth enthroned is based on a work attributed to miniaturist Levina Teerlinc. Roy Strong, Gloriana, the Portraits of Queen Elizabeth I (London: Pimlico, 2003), pp. 55-57. Also see John N. King, Tudor Royal Iconography (Princeton: Princeton University Press, 1989), pp. 154-158.

15 King suggests that the third figure is not Cecil, but Thomas Norton. See King, Tudor Royal Iconography, p. 156. For the Cecil attribution, see Evenden, Patents, Pictures and Patronage, p. 113-114.

16 Evenden, Patents, Pictures and Patronage, p. 107. The Lambeth edition is the only copy in which the Litany was written entirely in the first person. William Keatinge Clay states, 'Whilst, therefore, the rest of the impression was printed for the public generally, this particular book must have been prepared expressly for the Queen'. Clay, Private Prayers, p. xxi.

17 Lambeth Palace Library, Featured Image: Queen Elizabeth I Prayer Book, [<http://www .lambethpalacelibrary.org/content/elizabethprayerbook> accessed 29 November 2018]; Stróbl, 'The Queen and Death', p. 15. For more on Parker's workshop of binders and illuminators, see Anthony Grafton, 'Matthew Parker: The Book as Archive' in History of Humanities, Vol. 2, No. 1 (2017), p. 28. 


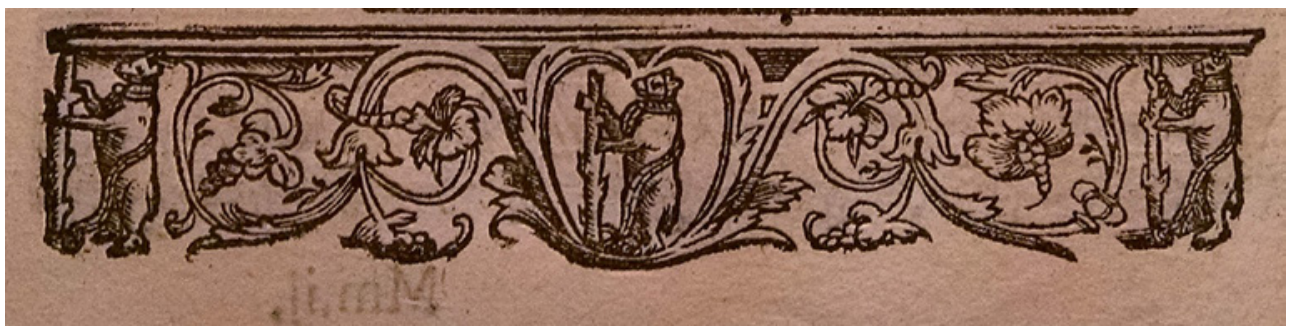

FIGURE 16.2 Ornament featuring the heraldic device of the Earl of Leicester from A Booke of Christian Prayers (1578), sig. $\mathrm{M2}^{\mathrm{v}}$ BRITISH LIBRARY

bear and staff, encircled in a heart of grape vines, appears 18 times in the first edition of $A$ Booke of Christian Prayers (see figure 16.2).

The royal arms and emblems associated with Tudor monarchs, such as roses, shamrocks, fleurs de lys and Beaufort portcullises are also woven throughout the works. Both prayer books feature a prefatory portrait of Queen Elizabeth having set aside the symbols of her authority - her crown, sceptre and sword and kneeling in private prayer at a prie-dieu with a little book open before her (see figure 16.3). ${ }^{18}$ This prefatory portrait, entitled Elizabeth Regina, echoes representations of the Old Testament kings, David and Solomon. To underscore this connection further, the epigraph cites 2 Chronicles 6:14, the prayer Solomon gave to dedicate to the completed Temple. The modelling of Elizabeth as a latter-day Solomon reverberates throughout the texts of both of Day's compilations and relates to the wider agenda of the works..$^{19}$ The association with the pious king Solomon seeks to legitimise the contemporary Church of England by claiming its own biblical prefigurations.

The Elizabeth Regina portrait is also positioned in the space often reserved for the portrayals of the Virgin in both print and manuscript books of hours. ${ }^{20}$

18 Most scholars refer to this image as a 'frontispiece'. However, because of its position on the verso of the leaf following the title page $\left(\mathrm{a}^{\mathrm{v}}\right)$, this paper is conforming to Ruth Samson Luborsky and Elizabeth Morley Ingram's more general designation of 'prefatory portrait'. For more on this portrait, see King, Tudor Royal Iconography, p. 114.

19 For more on casting Elizabeth as the new Solomon in Day's prayer books, see Linda Shenk, Learned Queen The Image of Elizabeth I in Politics and Poetry (New York: Palgrave Macmillan, 2010), pp. 21-53.

20 Notable examples of illustrations of the Virgin used at the opening of a codex are The Hours of Mary of Burgundy (Flanders, c. 1475), Book of Hours of Richard III (London, c. 1420), and The Hours of Lorenzo Strozzi (Naples, 1478). This substation is not unique to these works, as Patrick Collinson states: 'It has been almost commonplace to observe that in Elizabethan England the image of the Virgin was replaced by that of the virgin queen in polite and even popular devotion'. Collinson, From Iconoclasm to Iconophobia, p. 23. 


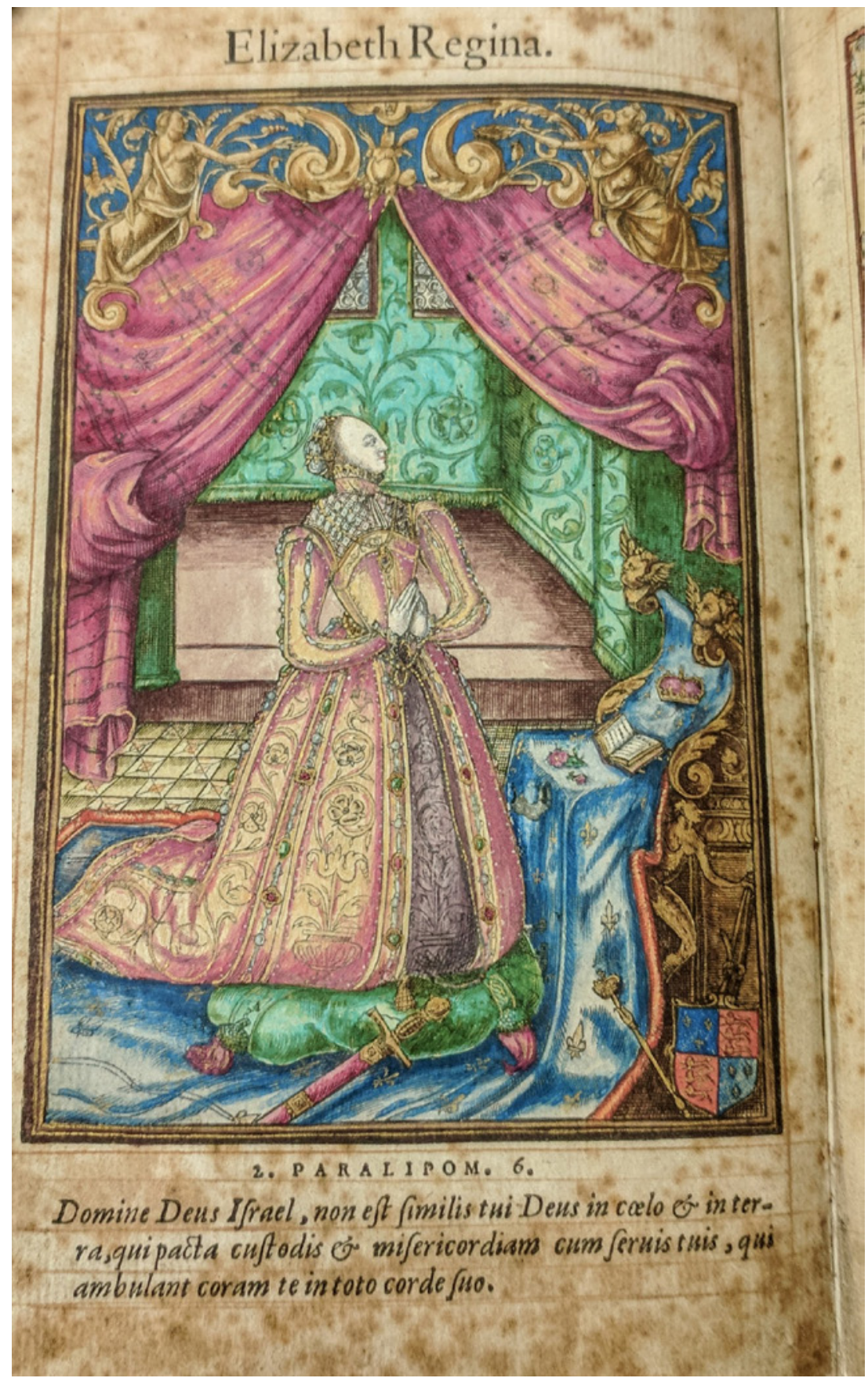

FIGURE 16.3 Elizabeth Regina. Prefatory portrait from A Booke of Christian Prayers (1578), sig. [fist] $\mathbf{1}^{\mathrm{v}}$

LAMBETH PALACE LIBRARY, SHELFMARK $[\mathrm{ZZ}] 1569.6$ 
The placement and composition honours the piety of the Queen while providing viewers with an unimpeachable example of the proper use of the book in hand. ${ }^{21}$ The depiction shows Elizabeth in her opulently decorated private chapel, but there is nothing in the room that would trouble even the most fervent of Elizabethan iconoclasts. This image is clearly a fiction. As we know from the work of Margaret Aston, the Queen's chapel was a site of continual iconoclasm and image restoration. Aston remarks that, over the course of many years, 'Elizabethan Polyeuctes ... bravely undertook to destroy the idols in the royal pantheon', only to see the offending cross and candlesticks reappear. ${ }^{22}$ Despite this imagined space, the badges of the monarch and her favourite express the agenda of the books while framing the devotional material with the trappings of authority.

While the visual rhetoric of authority in the work is clear and unwavering, the wider illustrative programme is far from stable. The shifting visual schemes of Christian Prayers and Meditations and A Booke of Christian Prayers makes them especially fertile sources for examining the changing mentality regarding religious images throughout their print run. In 1945, Samuel C. Chew noticed that when Richard Day reused the blocks from Christian Prayers and Meditations to make the first edition of his A Booke of Christian Prayers in 1578, he excised two images of Mary. ${ }^{23}$ The two Pietàs featured in the 1569 Christian Prayers and Meditations were clearly no longer acceptable for the $1578 \mathrm{~A}$ Booke of Christian Prayers (see figure 16.4). Given the Pietà's strong association with the Cult of Mary and papal indulgences, their removal was almost certainly induced by a need to conform this state-sanctioned work to the current religious climate.

The first 1569 Pietà is accompanied by two Old Testament prefigurations from Ruth and Lamentations, while the second is shown with prefigurations of Joseph being lowered into the pit and Jonah cast overboard. ${ }^{24}$ The Pietàs were replaced in 1578 by new cuts of the Entombment and the Maries visiting the Tomb (see figure 16.5). ${ }^{25}$ The method of excising the Pietàs remains a matter of debate. Chew and others believe that the border images are woodcuts, and that each Pietà and two prefigurations were a single vertical woodblock.

21 For Elizabeth as a user of books in royal iconography, rather than depicted like her father and brother as active participants in book production and dissemination, see Evenden, Patents, Pictures and Patronage, pp. 115-116. Portrait (Cambridge: Cambridge University Press, 1993), pp. 102-107.

23 Chew, 'Iconography', pp. 293-305.

24 Christian Prayers and Meditations (London: John Daye, 1569), ustc 39731, sig. e2 ${ }^{\mathrm{r}}$ and e2 ${ }^{\mathrm{v}}$.

25 A Booke of Christian Prayers (London: John Daye, 1578), USTC 508554, sig. L1 ${ }^{\mathrm{v}}$ and L2 ${ }^{\mathrm{r}}$. 

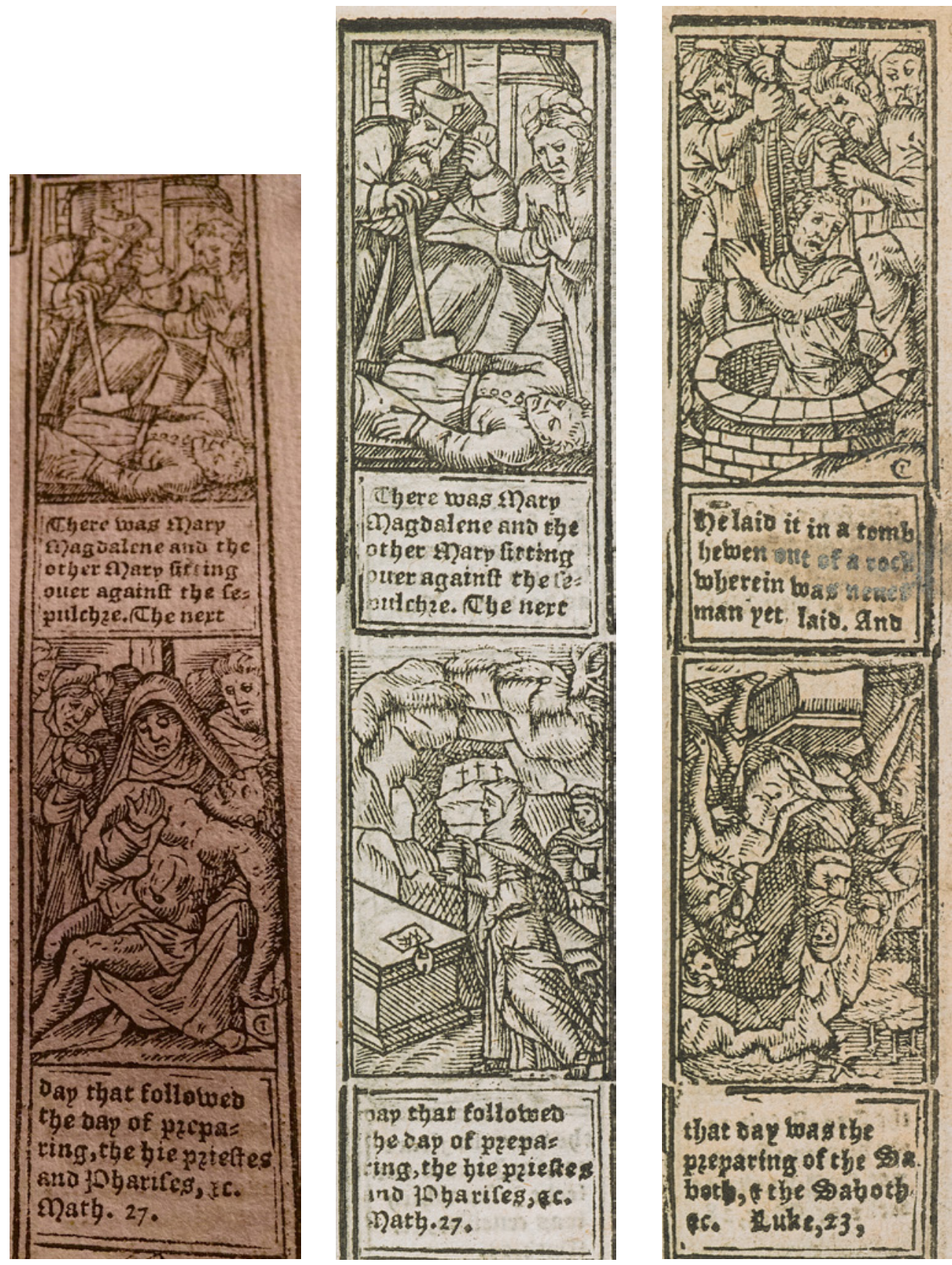

FIGURES 16.4-16.6 (left) One of two Pietàs from Christian Prayers and Meditations (1569), sig. E2 $2^{\mathrm{r}}$.

St Paul's Cathedral Library; (middle) Replacement Maries visiting the Tomb from A Booke of Christian Prayers (1578), sig. L2 ${ }^{\mathrm{r}}$. The British Library; (right) Upside down Entombment from A Booke of Christian Prayers (159o), sig. $\mathrm{Fr}^{\mathrm{r}}$

THE BRITISH LIBRARY 
In contrast, Leslie Manhin Oliver and the bibliographers of $A$ Guide to English Illustrated Books, Ruth Samson Luborsky and Elizabeth Morley Ingram contend that the borders were composed of metalcuts produced by a process known as polytypage. ${ }^{26}$ If the latter group is correct, the three images would have been cast separately, and only bound to each other once in the printer's matrix, allowing for easier alterations.

The new images were slotted into the same positions as their predecessors and are immediately recognisable as having been crafted by a different hand. In later editions, this micro-iconoclastic endeavour is made even clearer by the fact that, in the 1581,1590 and 1608 editions, at least one of the replacement images was printed upside down (see figure 16.6). As Chew states, 'in comparing these embellishments in their original and altered forms we have before our eyes the process of uprooting and destroying "Romish" images.27 By making that very comparison, we see that what was deemed admissible in 1569 needed to be expurgated only nine years later.

Unlike the above case of iconoclasm within the pages of Day's devotional works, some iconographic boundaries did not take years to shift; rather, they shifted in the course of printing. Three of the blocks from A Booke of Christian Prayer received substantive alterations, and two of them are present in the 1569 work in both their altered and original forms. Prefiguring Jesus being pierced by the Holy Lance is an image depicting Eve being brought forth from Adam's side. In the image, God is depicted as an old, bearded man wearing a voluminous robe and bending down towards the supplicant Eve, while his left hand reaches out to Eve's shoulder and his right is blessing her. After several quires with the anthropomorphic representation of the God had been printed, suddenly, God's head is chunked out and replaced with a tetragrammaton in a cloud (see figure 16.7) ${ }^{28}$ The block was cut with a diagonal incision that manages to excise God's face and right hand while keeping Eve intact. The substitution is rather clumsy: behind the recumbent figure of Adam, the viewer can still see God's billowing robes, and his left hand, still reaching toward Eve, has been disembodied. Out of the seven times this image is printed in the Christian

26 Leslie Mahin Oliver, 'The Procession of the Virtues in a Book of Christian Prayers' in Harvard Library Bulletin, vi (1952), p. 308; Ruth Samson Luborsky and Elizabeth Morley Ingram, A Guide to English Illustrated, Books 1536-1603 (Ann Arbor: University of Michigan, 1998), p. 315 .

27 Chew, 'Iconography', p. 300.

28 For more on the history of the tetragrammaton in English print, see David J. Davis, Seeing Faith, Printing Pictures: Religious Identity during the English Reformation (Leiden: Brill, 2013) pp. 143-177; Margaret Aston, 'Symbols of Conversion: Proprieties of the Page in Reformation England', in Michael Hunter (ed.) Printed Images in Early Modern Britain: Essays in Interpretation (Aldershot: Ashgate, 2010). 

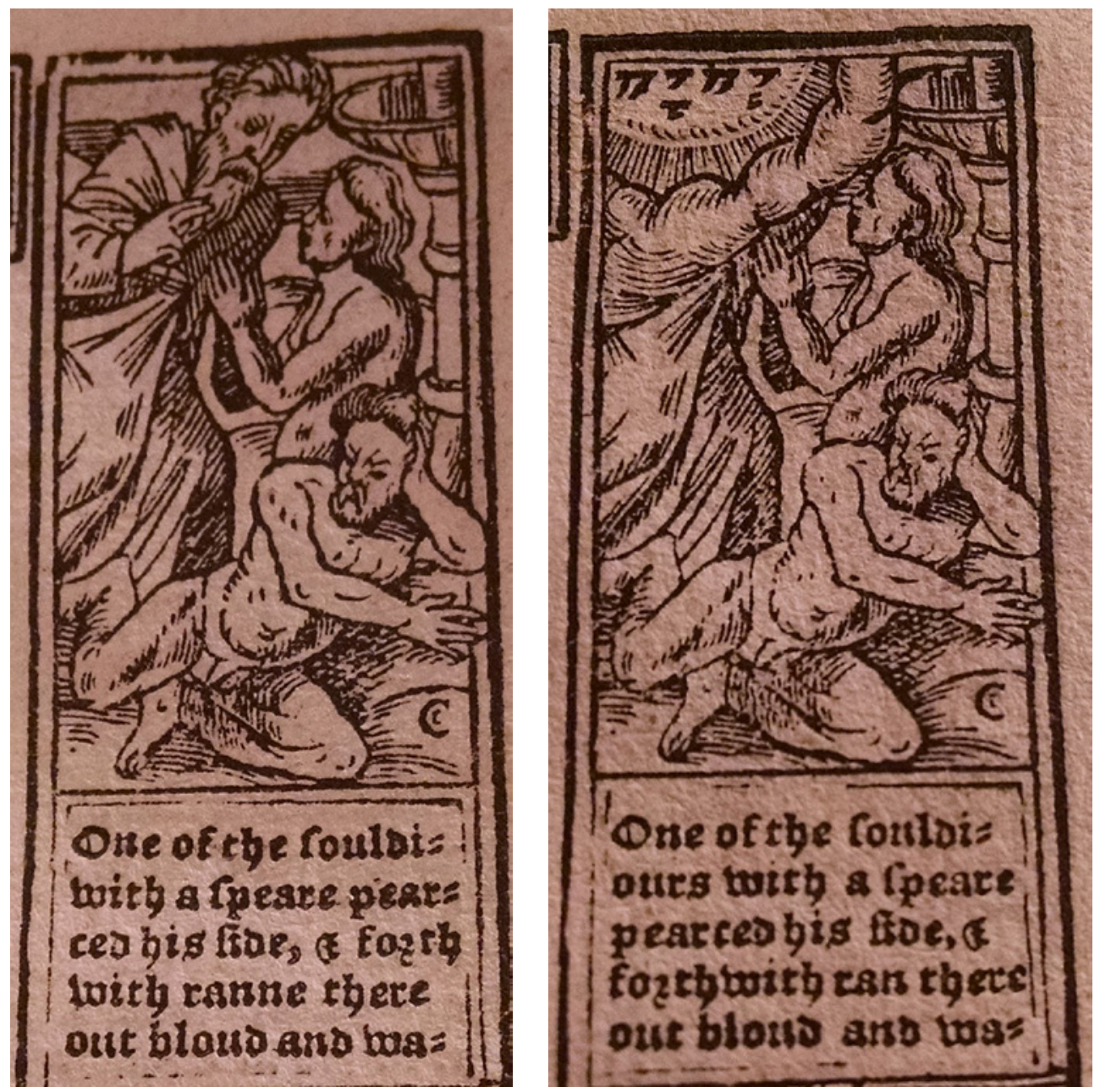

FIGURE 16.7 The Creation of Eve from Christian Prayers and Meditations (1569), sig. $\mathrm{e1}^{\mathrm{r}}$ and $^{\mathrm{o}} 4^{\mathrm{r}}$ ST PAUL'S CATHEDRAL LIBRARY

Prayers and Meditations, three feature God as human, and four have the tetragrammaton replacement. ${ }^{29}$

This same disruption occurred twice more in the work. Following a similar procedure to the altered Creation of Eve woodcut, in the illustration of Moses taking off his shoes at God's request from Exodus 3, God was replaced with the tetragrammaton (see figure 16.8). Again, in the edited impressions, the

29 USTC 39731. God the Father is featured on sig. $\mathrm{er}^{\mathrm{r}}, \mathrm{Er}^{\mathrm{r}}$, and $\mathrm{Dd} \mathrm{r}^{\mathrm{r}}$, while sig. $\mathrm{i} 4^{\mathrm{r}}, \mathrm{o}^{\mathrm{r}}, \mathrm{K}^{\mathrm{r}}$, and $\mathrm{Ii}^{\mathrm{r}}$ have the tetragrammaton edits. 

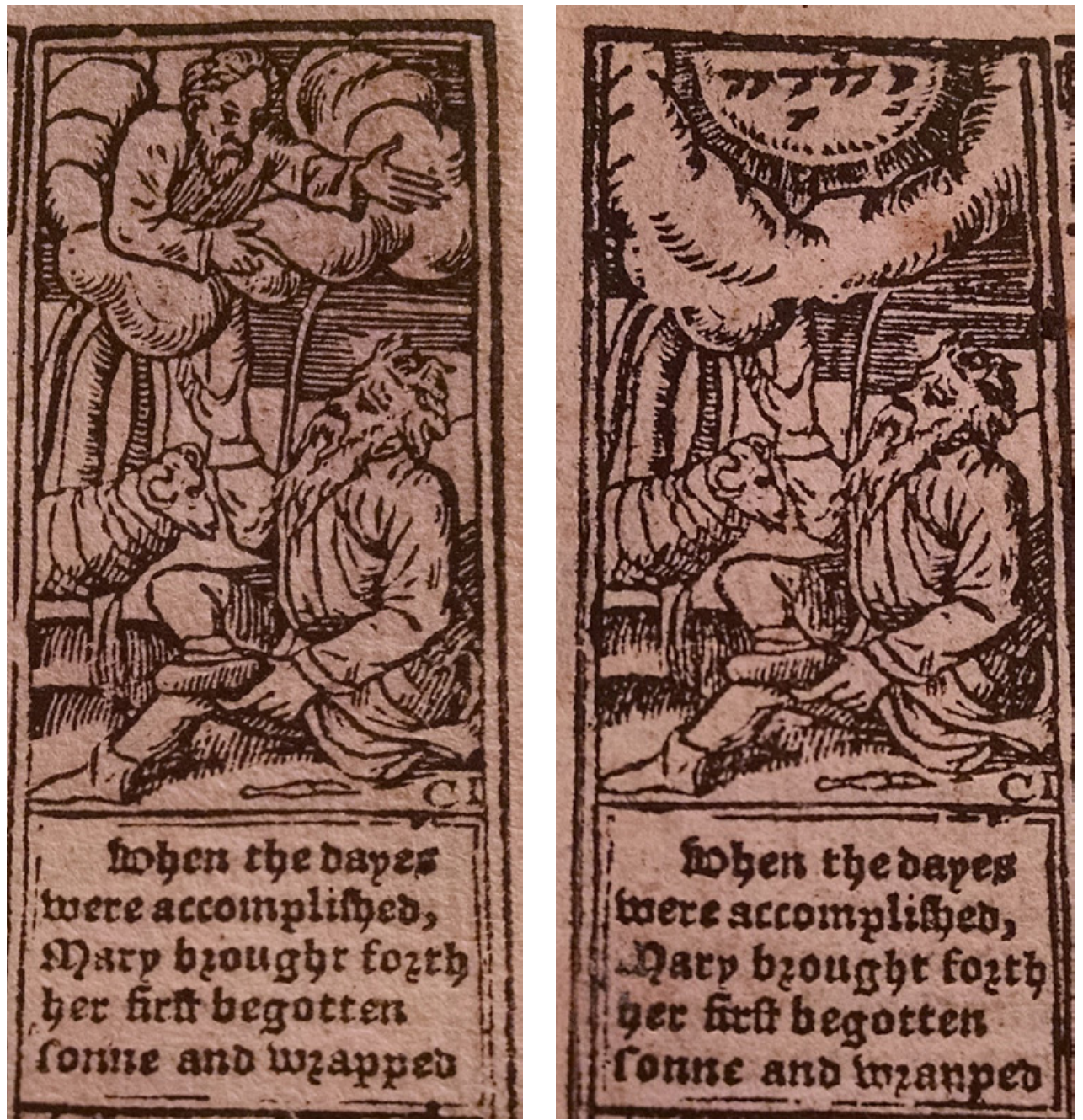

FIGURE 16.8 Moses before the burning bush from Christian Prayers and Meditations (1569), sig. A $3^{\mathrm{r}}$ and $\mathrm{L}_{4}^{\mathrm{r}}$

ST PAUL'S CATHEDRAL LIBRARY

anthropomorphic God is still visible from the waist down. ${ }^{30}$ Finally, all seven instances of the image of David praying to God from Samuel 2 have clearly had the same treatment, but no pre-edited version made its way into the work (see figure 16.9). ${ }^{31}$

$30 \quad$ USTC 39731. God the Father is featured on sig. $\mathrm{A}_{3}{ }^{\mathrm{r}}$ and $\mathrm{F}_{3}{ }^{\mathrm{r}}$, while sig. $\mathrm{a}_{4}^{\mathrm{r}}, \mathrm{f}_{4}{ }^{\mathrm{r}}, \mathrm{l}_{2}{ }^{\mathrm{r}}, \mathrm{L}_{4}^{\mathrm{r}}$, and $\mathrm{Ee}_{3}{ }^{\mathrm{r}}$ have the tetragrammaton edits.

31 USTC 39731 , sig. $4_{4}{ }^{\mathrm{r}}, \mathrm{g}_{3}{ }^{\mathrm{r}}, \mathrm{m}_{2}{ }^{\mathrm{r}}, \mathrm{B}_{3}{ }^{\mathrm{r}}, \mathrm{G}_{3}{ }^{\mathrm{r}}, \mathrm{L}_{4}^{\mathrm{v}}$, and $\mathrm{Ff}_{2}^{\mathrm{v}}$. 


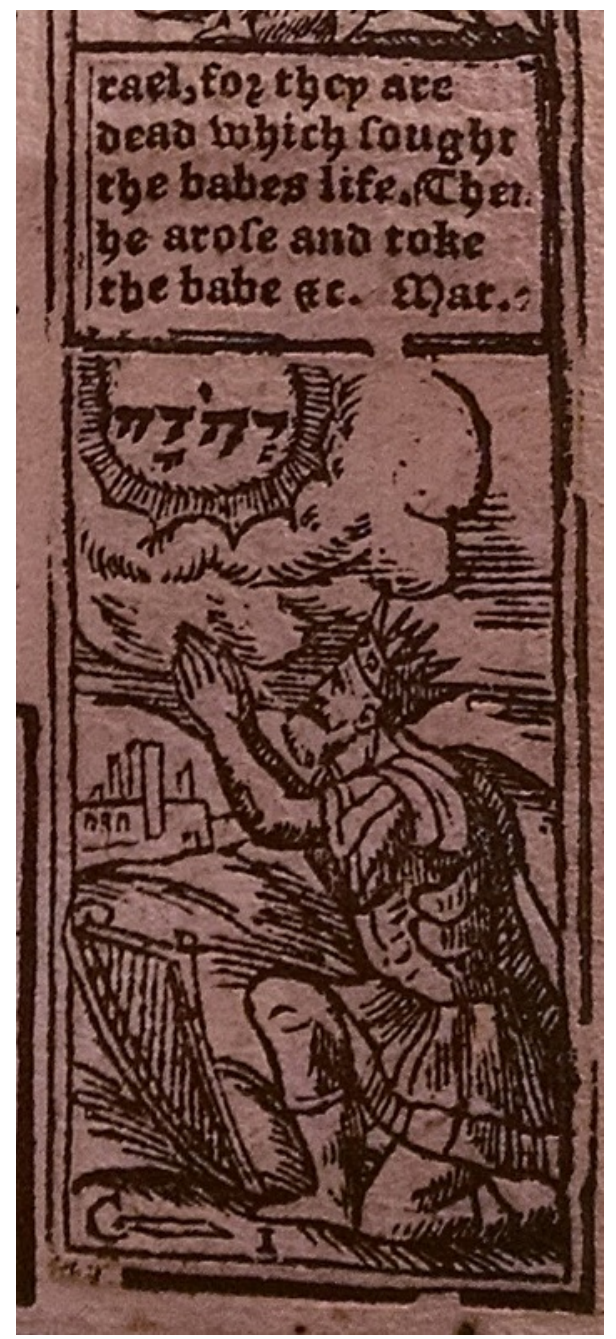

FIGURE 16.9

David praying about his return to Judah from Christian Prayers and Meditations (1569), sig. $4_{4}{ }^{\mathrm{r}}$ ST PAUL'S CATHEDRAL LIBRARY

Uncommented on in the literature on Day's prayer books is the tiny anthropomorphic God handing Moses the Decalogue in the background of the Golden Calf cut. ${ }^{32}$ This depiction of a bearded God avoided the editorial decapitation exacted on the images cited above, and remained unaltered in the subsequent editions of $A$ Booke of Christian Prayers. Although this image escaped expurgation in the four print shops that used this cut from 1569-1608, the artists charged with colouring the Queen's personal copy caught the unwelcome guest and diligently blotted him out. In each of the above cases, the artists in Parker's Lambeth workshop skilfully blended any traces of the personified God 


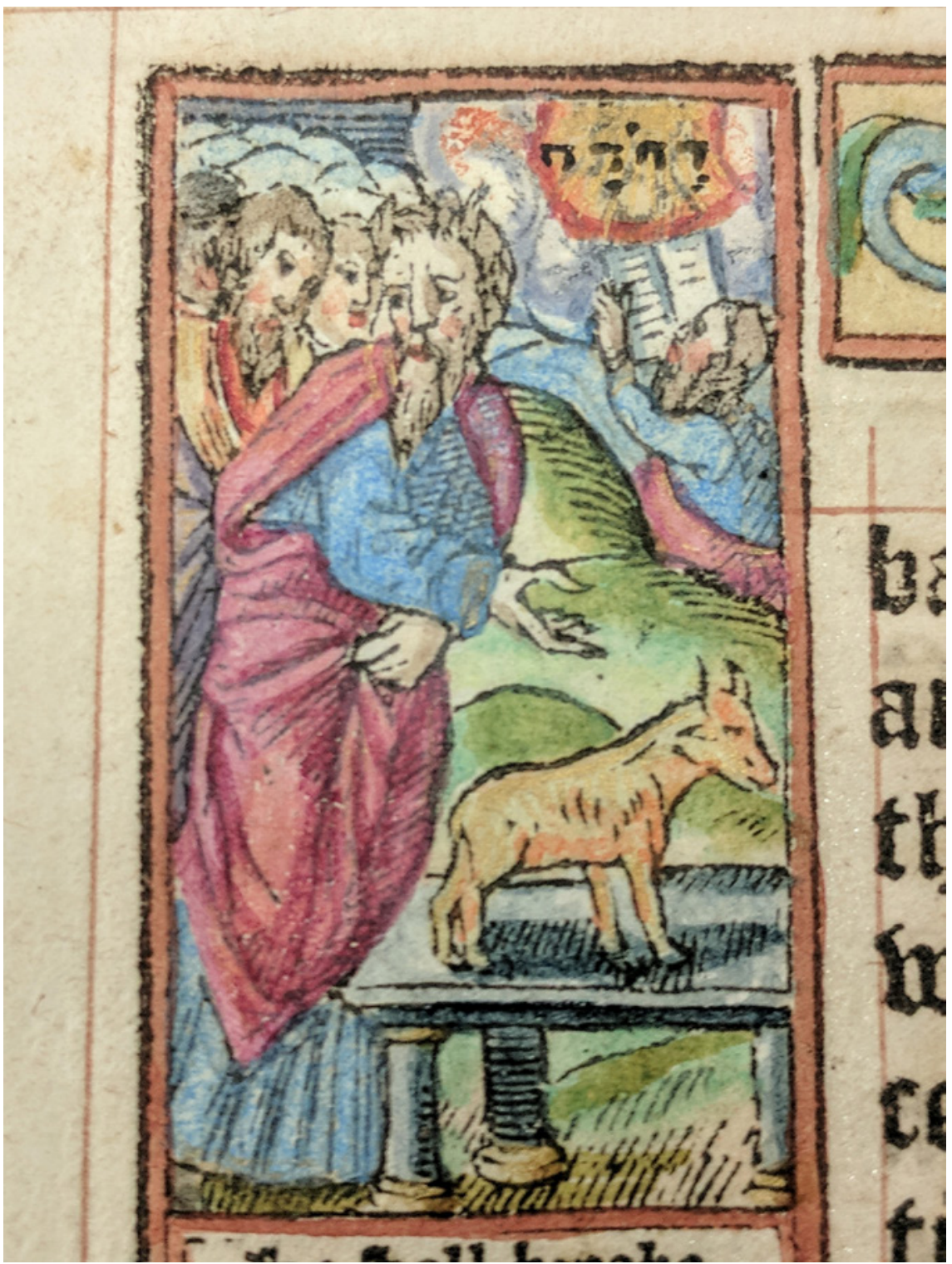

FIGURE 16.10 Hand-coloured Moses and the Golden Calf, with a manuscript Tetragrammaton covering God in a cloud THE LAMBETH PALACE LIBRARY, SHELF MARK [ZZ]1569.6 
into the background, and, for some impressions, even delicately added manuscript tetragrammatons (see figure 16.10).

Aston's often-cited unpacking of the complex events surrounding the Bishops' Bible controversy provides insight into the iconoclasm in Christian Prayers and Meditations. The Bishops' Bible of 1568 was conceived by Archbishop Parker to provide a more authoritative English translation. Parker's Bible included 134 woodcut illustrations based on the work of German artist Virgil Solis, printed from blocks that Aston proved were brought to England from Cologne. ${ }^{33}$ Solis' compositions were Lutheran in origin, but were also deemed acceptable for use in a series of Catholic Bibles. Aston describes a process remarkably similar to that of the refashioning of Day's books:

... some of the blocks were carefully altered to suit the confessional demands of the Elizabethan Church.... Prints that included large depictions of God were reworked. The offending section was cut out, a plug of new wood deftly inserted into the block, and a wood-engraver filled the sometimes awkward space with the tetragrammaton. ${ }^{34}$

As in Christian Prayers and Meditations, the Bishops' Bible's Creation of Eve scene was modified by replacing the representation of God as a bearded ancient with a tetragrammaton.

The anxiety about depicting God the Father had long been stirring in England. Archbishop Cranmer's Catechism of 1548 attacks images of God as 'an olde man with a long hore berd', and between 1559 and 156o, one of the 11 Articles by the Bishops of Lambeth stated that the clergy should twice yearly preach that they 'utterly disallow ... all kind of expressing God invisible in the form of an old man'. ${ }^{35}$ Parker's purging fell in line with English Protestant tastes, but, to his critics' delight, his biblical iconoclasm was not entirely thorough. Several smaller woodcut images of the anthropomorphic God made their way into the first edition of the Bishop's Bible. The 1572 A Second Admonition to the Parliament featured a brutal attack on these images: '... in their last great Bible in the first edition of it, such a sight of blasphemous picture of God the father, as what they deserve for it, I will refer them to none other judge then their owne note uppon the 15 verse of the fourth of Deuteronomie ....36 The

33 Margaret Aston, 'The Bishops' Bible Illustrations' in Diana Wood (ed.), The Church and the Arts (Cambridge: Ecclesiastical History Society, 1992), p. 271.

34 Aston, 'The Bishops' Bible Illustrations', pp. 283-284.

35 Aston, 'The Bishops' Bible Illustrations', p. 280 ; Gerald Lewis Bray (ed.) Documents of the English Reformation 1526-1701, (Cambridge: James Clarke \& Co., 2004), pp. 349-351. USTC 504011, sig. C $8^{\mathrm{v}}-\mathrm{Di}^{\mathrm{r}}$.

36 Aston, 'The Bishops' Bible Illustrations', p. 272. The note to which the critics refer was written by Bishop Alley to clarify God's words on Mount Horeb and read: 'Meaning that 
Admonition closes by teasing its readers with an anonymous colophon, stating 'Thys worke is finished thankes be to God/And he only wil keepe us from the searchers rod. And though master [John] Day and [Humphrey] Toy watch \& warde/ We hope the living God is our savegarde ....37

The contemporary controversy surrounding the images in the Bishops' Bible sheds light on the similar changes made during the printing of Christian Prayers and Meditations. As Day's patron, Parker played an important part in the dissemination of Christian Prayers and Meditations. Evenden explains that, in 1568, shortly after Parker presented Elizabeth with a copy of the Bishops' Bible, the Archbishop presented her with the hand-coloured copy of Christian Prayers and Meditations. ${ }^{38}$ The two books were published only months apart, and, although the criticism cited above was from 1572, it has been argued that outrage over the images in this high-profile book was also voiced immediately. ${ }^{39}$ Therefore, while Day was in the midst of printing, it is probable that the outcry over the depiction of God was starting to break out. This contemporary public indignation could explain the apparent hastiness of the excisions of God's face.

There is material evidence to suggest that Day set about his iconoclasm immediately. In a work composed of three different paper stocks, an edited and unedited image of the Creation of Eve is printed on paper with identical watermarks, implying that the images were printed in a relatively short span of time..$^{40}$ Williams asserts that these changes are proof of Day's self-censorship, rather than censorship having been imposed upon him by outside authorities. If the deletion of the anthropomorphic God was the work of the body of clerical censors put in place in the Royal Injunctions of 1559 , it is unlikely that they would have allowed the images of the human manifestations of God that were already printed to remain in the work. ${ }^{41}$

From these examples of iconoclasm within the pages of Christian Prayers and Meditations and A Booke of Christian Prayers, we see the complexities of Day's role as an image producer. Clearly, he was beholden to the limits on

plagues hang over them that would make any image to represent God by' USTC 506837, sig. D6 ${ }^{\mathrm{r}}$.

37 [Thomas Cartwright], A second admonition to the parliament ([Hemel Hempstead: John Stroud, 1572]), USTC 507415, sig. $\mathrm{H}_{5}^{\mathrm{r}}$. The colophon plays with Day's title as the Warden of the Stationers' Company and Toy's terms as Under-Warden in 1571. See Greg and Boswell (eds.), Records of the Court of the Stationers' Company, p. 95; Evenden, Patents, Pictures and Patronage, p. 79 .

38 Evenden, Patents, Pictures and Patronage, p. 107.

39 Williams, 'Censorship', p. 57.

40 Watermarks observed in the St Paul's Cathedral Library copy (Shelfmark.24A) of USTC 39731, sig. e1 ${ }^{\mathrm{r}}$ and $04^{\mathrm{r}}$.

41 Williams, 'Censorship', p. 57. 
iconographic depictions that were already in place. In Christian Prayers and Meditations, this meant the speedy, if uneven, censorship of the image of God, and his replacement with a more abstract representation that emphasises the Word over a physical depiction. In A Booke of Christian Prayers, this tension manifests in editing blocks to exclude the images of the Pietàs, with their associations with idolatry and indulgences. However, Day's official status meant that he was not just reacting to changes in orthodoxy, but also actively involved in presenting acceptable images and establishing the new boundaries.

\section{Fashioning the New Orthodoxy}

Much of the Elizabethan discourse on the role of images in devotion conformed to the writings of Calvin. For Calvin and for the Elizabethan Church, it was the intent behind an image that marked it as idolatrous or permissible. Calvin simplifies this distinction by explaining the two classes of acceptable representations:

historical, which give a representation of events, and pictorial, which merely exhibit bodily shapes and figures. The former are of some use for instruction or admonition. The latter, so far as I can see, are only fitted for amusement. ${ }^{42}$

However, in practice, the exact definition of an 'un-abused' image was vague, and, as we have already seen in this paper, subject to changes. Therefore, Day took great pains to cite the biblical and historical sources for the images in his prayer books while stressing their educational intention.

Starting on leaf M1, the visual scheme of the 1578 A Booke of Christian Prayers' borders shifts to a cycle portraying representations of the Virtues, which were not featured in the earlier Christian Prayers and Meditations. The Virtues were expanded from the traditional seven Christian Virtues typically found in the iconographic program of printed books of hours. ${ }^{43}$ These borders personify each Virtue as a psychomachic figure trampling the embodiment of the corresponding vice underfoot. ${ }^{44}$ This effective format for depicting spiritual conflict is used for 22 different Virtues throughout the work, and depicts battles such

42 John Calvin, Henry Beveridge (trans.), Institutes of the Christian Religion: A New Translation (Edinburg: Calvin Translation Society, 1845), Book I, p. 113.

43 Oliver, 'Virtues', p. 303.

44 King, Iconography, pp. 118-122. 
as 'Industry's' victory over 'Sloth' or 'Sobriety's' conquest over 'Voluptousnesse'. In the 1578 and 1581 editions, one of these images speaks directly to the danger of improper use of images in devotional practices. ${ }^{45}$ The crowned figure identified as the 'Love of God' is portrayed as victorious over 'Idolatry' (see figure 16.11). Her depiction indicates that she was adapted from the traditional image of 'Charity' found in printed books of hours. ${ }^{46}$ Unlike 'Charity', who typically is shown conquering a personification of 'Heresy', 'Love of God' is trampling the objects used in Catholic sacraments and rituals. Under 'Love of God's' feet, the viewer sees a bishop's crosier, chalice, scourge, rosary, Eucharist wafer, candlestick, crucifix and a pax that features an image of a figure praying. Directly below the defeated objects, the letterpress caption informs the reader that 'Idolatry, is Spirituall adultery'. The psychomachic rhetoric makes it abundantly clear that objects associated with Roman Catholicism and image worship are not viable ways to access true love of God.

The page's pedagogical message does not end with the depiction of 'Love of God'. Accompanying the virtue every time she appears in the work is a footpiece that details the sacrament of Communion. In contrast to the defeated Catholic wafer, the minister in the footpiece hands out pieces of bread torn from a large loaf. ${ }^{47}$ Similarly, juxtaposing the vanquished chalice, with its long stem and small cup that was intended for the priest's use during the sacrament, the footpiece depicts a wide-mouthed cup that the minister could share with parishioners in a Protestant service. ${ }^{48}$ Both the cup and the loaf of common bread are placed upon a table completely bare of decoration within the body of an equally unadorned church. This adversarial and dependent pairing works to destroy the validity of the Catholic sacrament while presenting in its place a positive image of Protestant service. In effect, the viewer witnesses the

45 Expanding on Chew, Mahin Oliver notes that this image (and 'Knowledge of God' which will be discussed below) 'were lost from the book after the 1578 impression'. This is not entirely accurate: both these images are present on $\mathrm{R}^{\mathrm{v}}$ and $\mathrm{R}_{2}{ }^{\mathrm{r}}$ of the 1581 edition, but are not found in the two later editions. Oliver, 'Virtues', p. 307. Chew, 'Iconography', p. 302.

46 Oliver, 'Virtues', p. 305.

47 Christopher Haigh explains that in the controversy and confusion over the use of common bread or unleavened wafers, traditionalists (including Queen Elizabeth and Parker) advocating for the customary wafers and hard-line Protestants sided with the $155^{2}$ Book of Common Prayer's call for 'bread be such as is usual to be eaten at the table'. By the time of this printing in 1578, conservatives had mostly conceded and Archbishop Sandys' metropolitan visitations of that year reinforced the use of common bread. Christopher Haigh, "A matter of much contention in the realm": Parish controversies over communion bread in post-Reformation England', History, 88 (2003), pp. 393-404. 


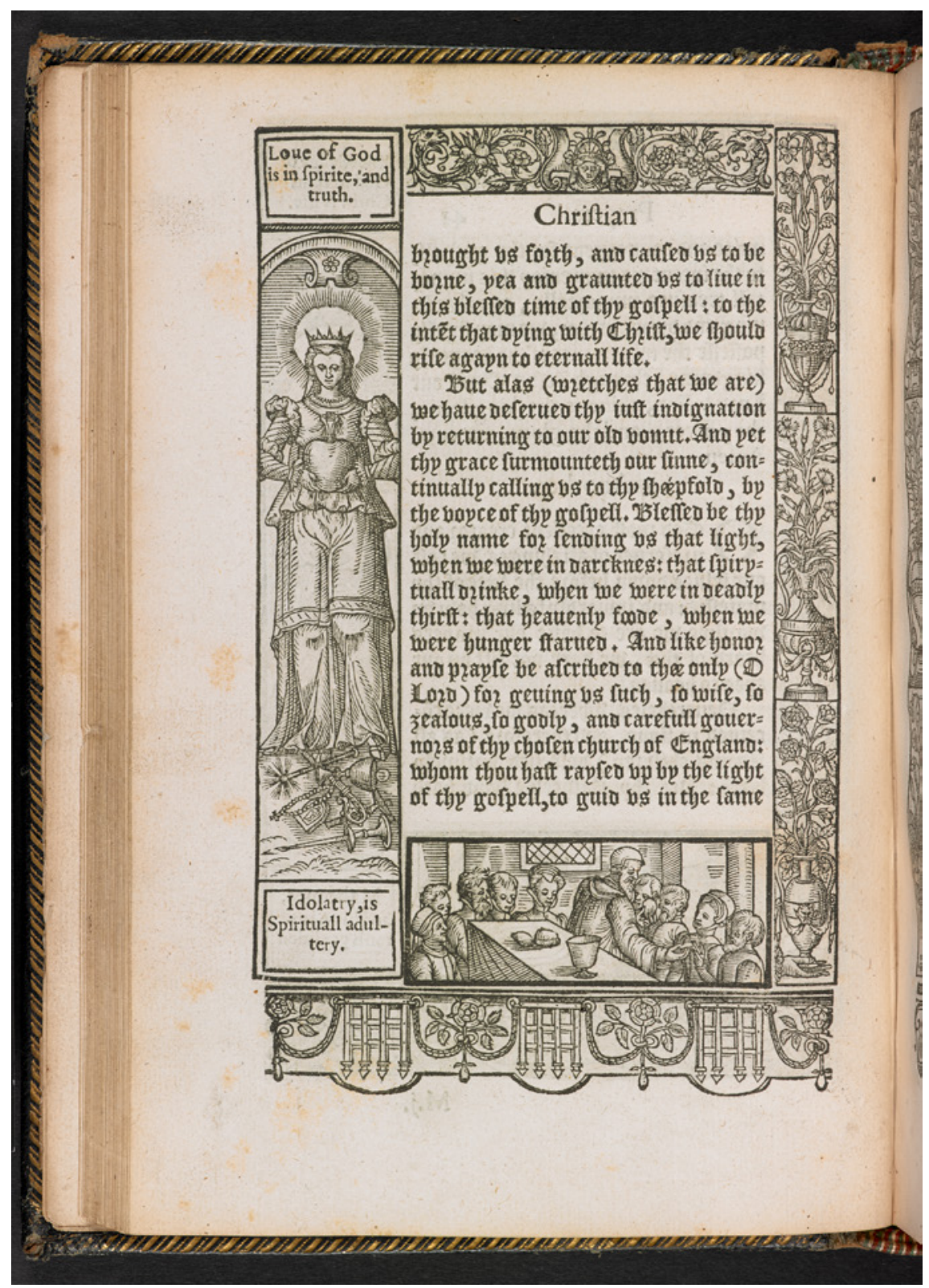

FIGURE 16.11 'Love of God' and 'Idolatry' and Communion from A Booke of Christian Prayers (1578), sig. Miv

THE BRITISH LIBRARY 
moment of victory in the battle over idolatry and is then presented with the ideal, purified result.

The 'Love of God' and Communion pair is not the only illustration within $A$ Booke of Christian Prayers that presents an image of a Protestant sacrament. In the border directly preceding 'Love of God' is the related Virtue of 'Knowledge of God', who is shown with a burning taper and open book and is trampling 'Mahomet'.49 Paired with 'Knowledge of God' is an image of the other gospel sacrament of Baptism. In the image, a swaddled infant is held over an unembellished baptismal font while the minister sprinkles water over its head. This representation is a conscious departure from the Sarum rite, which called for the immersion of the naked baby (see figure 16.12)..$^{50}$ In each of these pairs, we see Day's attempt to construct a new set of images to direct devotions and edify his readers. These are not the meditative or venerable images found in previous books of hours; rather, they are strictly pedagogical.

In each of these sacramental images, the minister is shown wearing a surplice. The years preceding the publication of $A$ Booke of Christian Prayers were plagued with controversy about the authority of the regulation of trivial aspects of the church, or adiaphora, and the outfitting of ministers was at the centre of the controversy. ${ }^{51}$ The issue of ecclesiastical dress divided the clergy, with conservatives supporting the traditional vestments that the Queen and Archbishop Parker demanded be maintained. On the other side, nonconformists, such as Bible translator Miles Coverdale and Parker's successor Edmund Grindal, saw traditional clothing as a vestige of popery. By observing the surpliced ministers of the Communion and Baptism footpieces, the contemporary viewer is informed that $A$ Booke of Christian Prayers was not just a Protestant work, but a conservative Protestant work.

Day's, and his influential patrons', conservative message is reiterated in the Dance of Death cycles towards the end of A Booke of Christian Prayers. For the most part, the images in the Dance of Death cycles were taken from Christian Prayers and Meditations. However, the earlier Christian Prayers and Meditations only illustrated secular figures. A Booke of Christian Prayers expanded the cycle by depicting the futile struggle of 14 new members of English society, including figures identified as 'Archbishop', 'Bishop', 'Doctor' and 'Preacher.,52 As one might expect from the representations of the clergy in these sacramental

49 In respect of Muslim readers, this image is not reproduced here.

50 Eamon Duffy, 'Continuity and Divergence in Tudor Religion', in R.N. Swanson (ed.), Unity and Diversity in the Church (Cambridge: Ecclesiastical History Society, 1996), p. 202.

51 For an overview of the events of the vestments controversy, see Patrick Collinson, The Elizabethan Puritan Movement (Oxford Scholarship Online, 2011). For the issue of adiaphora and its influence over the image debate, see Davis, Seeing Faith, pp. 45-69. 


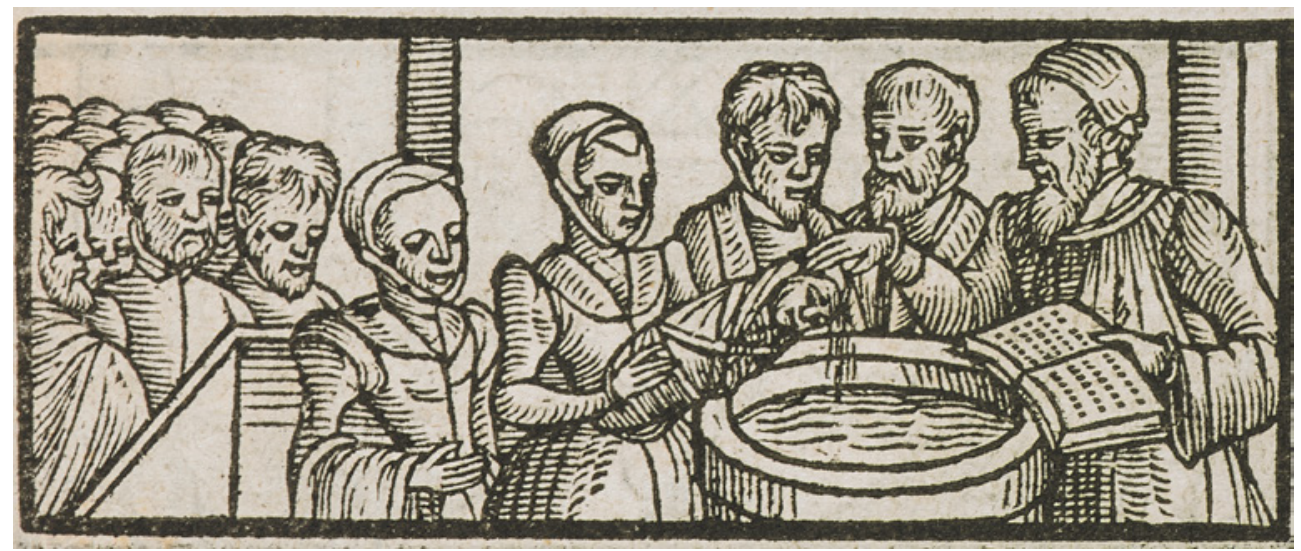

FIGURE 16.12 Baptism from A Booke of Christian Prayers (1578), sig. R1v THE BRITISH LIBRARY

images, the four ecclesiastical figures are outfitted in the conservative vestments. Yet again, the elaborate illustrations in the prayer book refashioned an iconographical trope to suit the new political and religious environment.

The images explored in this paper represent only a fraction of the massive illustrative content of the two books, but they are telling of the overall message of the work. While remarkably similar, the illustrations in Day's prayer books do not function like the prescribed meditative and devotional images in Catholic books of hours. In choosing the images to include in Christian Prayers and Meditations and A Booke of Christian Prayers, Day took measures to make sure that his readers did not see the illustrated borders as objects of veneration. He succeeded by ensuring that there would be little room for subjectivity. With copious biblical citations and prefigurations, controlled depictions of Protestant services, extant signs of editing and emblems of authority, the Reformed intentions of the images are clear. The images Day edited or substituted reflect the newly established boundaries of permissibility. Likewise, the pedagogical images Day added show how the reader was intended to understand the acceptable images he provided. With these tightly controlled illustrations, Day transformed the images in his borders from objects of reverence to reference.

\section{Repetition and Reception}

If, as I argue, Day was consciously appropriating the format of a book of hours to disseminate an acceptable English, Protestant iconography, it is worth examining how his readers interacted with and used the permissible images he 
published. Seventeenth-century antiquarian John Bagford praised Day's title pages because they were 'prented cut in vood finley designed [as was] his head peces and borders and tale peces with maney of his grat letters vsed in the dedications.' ${ }^{53}$ Aside from comments like Bagford's, the visual and textual marginalia added by early modern readers are important sources for the reception of Day's images. ${ }^{54}$ The amateur production of so-called 'doodles' and placement in the literal margins has led some historians to dismiss visual marginalia as the scratchings of bored children. However, when contextualized within the wider pictorial scheme and the illustrations they are frequently found near, a doodle suddenly becomes evidence of image reception.

In a copy of the 1578 A Booke of Christian Prayers, now in Northwestern University's theological library, one reader, Joshua Hilton, clearly spent a considerable amount of time looking at the 'finley designed' border images in his book. The visual marginalia he left behind show his copying of the key aspects that bind Jesus' instruction to 'take and eat' the bread at the Lord's supper with its Old Testament prefiguration of the Israelites receiving God's gift of manna (see figure 16.13). Although roughly executed, Hilton's copying of Jesus' hand passing the bread, and a bowl that an Israelite uses to catch manna, indicates that he saw and, more importantly, understood the images. On a later leaf, Hilton also copied an unidentified graver's mark hidden in most of the Life of Christ images. ${ }^{55}$ A marginal note in a 159 o edition of A Booke of Christian Prayers, now in the British Library, shows a contemporary hand coping the textual warning against idolatry, which contextualises the Adoration of the Magi (and destruction of an idol) composition in the Life of Christ series. Perhaps noting the small, personified God in the Golden Calf prefiguration, which was noted above, the reader transcribed 'He shall breake downe there altars he shall destroy their images', reminding himself, and later readers, of the peril of misusing religious images. ${ }^{56}$

Looking beyond the material page, we see that these books were not only an attempt to shape the public image of Elizabeth and her church, but were also

53 Quoted from Oastler, 'John Day, the Elizabethan Printer', p. 2. Oastler cites, B.M. Ms. Harl. 5910, II, f.12v.

54 For more on early modern marginalia see William H. Sherman, Used Books: Marking Readers in Renaissance England (Pennsylvania: University of Pennsylvania Press, 2010) and his forthcoming The Reader's Eye.

55 Marginalia observed in Northwestern University Styberg Library's copy (Shelfmark: BV245.D27) USTC 508554, sig. I3 ${ }^{\mathrm{v}}$ and Ee2 ${ }^{\mathrm{v}}$.

56 Marginalia observed in the British Library's copy of Richard Day, A booke of Christian prayers (London: Richard Yardley and Peter Short for the assigns of Richard Daye, 159o), USTC 511512, sig. C2 $2^{\mathrm{v}}$. Shelfmark: c.24.a.21. 


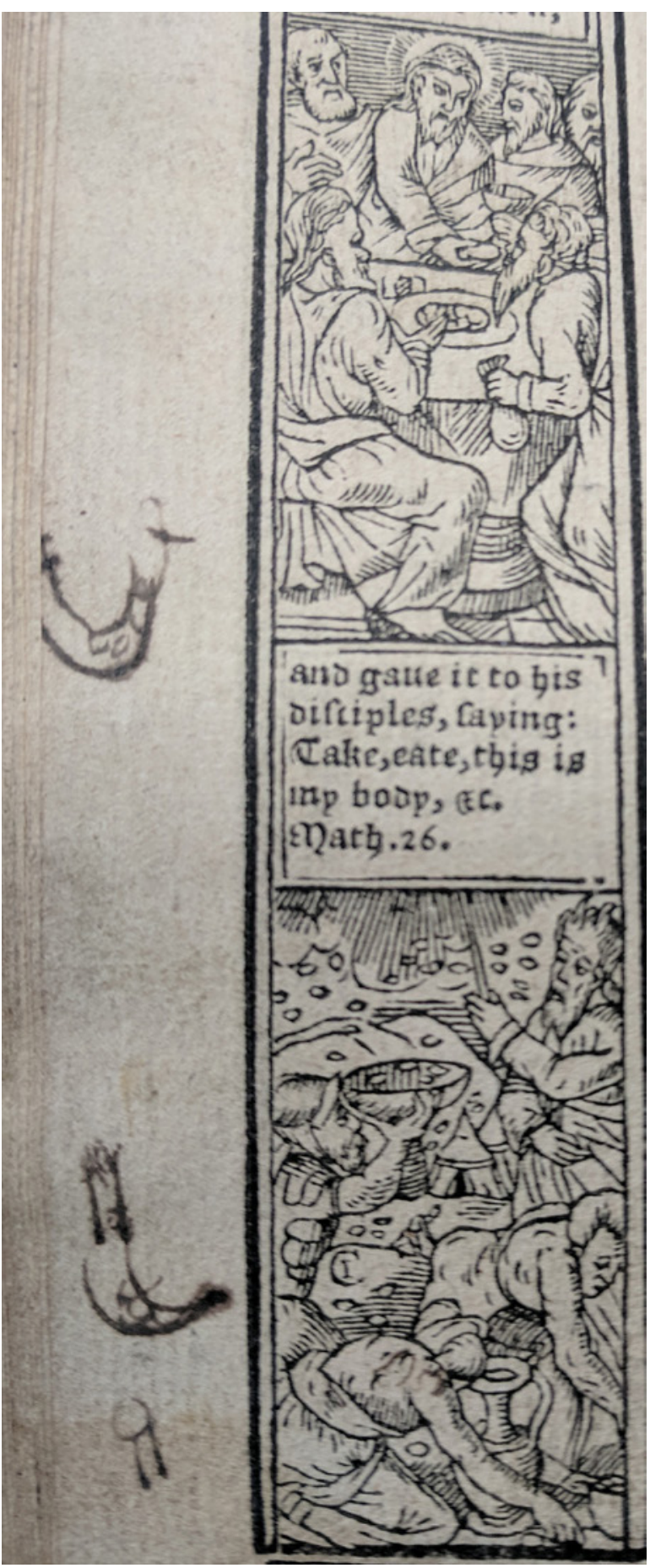

FIGURE 16.13

Joshua Hilton's

marginalia from $A$ Booke

of Christian Prayers (1578)

NORTHWESTERN

UNIVERSITY STYBERG

LIBRARY, SHELF MARK:

BV245.D27 
used by owners to fashion their own public images. As Tara Hamling explains, from 1570 to 1640 , the dramatic rise in construction and living standards created conditions that resulted in an increase in home building on nearly every level of the social scale. ${ }^{57}$ For Day's elite readers, a well-crafted public image was essential to maintaining status, and social conventions dictated that rank be expressed with material displays of wealth. ${ }^{58}$ This could prove problematic for committed Protestants, who were instructed to rejected vanity and conspicuous consumption. Many overcame these tensions by decorating their homes with images pulled from state-approved illustrated books.

Given the nebulous definition of acceptable images, the householder who patronised domestic decorations could inadvertently open himself, and his household, to idolatry or signify religious and political dissent if a poor selection was made. The stakes of choosing the correct subject become higher when one considers that the early modern English home was a semi-public space that reflected the social standing and godliness of the principal householder. By producing a vehemently reformed illustrated devotional work, Day provided a cornucopia of permissible images that could be adapted and reused in diverse media.

In her work Decorating the 'Godly' Household, Hamling identified a number of adaptations of images from Christian Prayers and Meditations and $A$ Booke of Christian Prayers into early modern English homes. Her research also suggests that it was the homeowner who dictated the decorative scheme of the household (and not the craftsmen and women who executed it), and that patrons mainly came from the mainstream Protestant majority who adopted the state-sponsored faith. ${ }^{59}$ One such conformist was Mark Hawkings, a prosperous fish merchant from North Devon, who built a townhouse around 1635, featuring a parlour with an elaborate plasterwork ceiling depicting the Tree of

57 Tara Hamling, Decorating the 'Godly' Household (New Haven: Yale University Press, 2010), p. 68.

58 Tara Hamling, 'The Appreciation of Religious Images in Plasterwork in the Protest Domestic Interiors', in Tara Hamling and Richard L. Williams, (eds.), Art Re-formed (Cambridge: Cambridge University Press, 2007), p. 15 o.

59 Hamling, 'Godly' Household, p. 20. Although significantly later, a 1688 contract between the Earl of Strathmore and Dutch artist Jacob de Wet directs that 15 ceiling panels will be painted with 'distinct stories of our blessed Saviour Confrome to the Cutts in a bible here in the house or the Service Book'. Patrick Lyon Strathmore and Alexander Hastie Millar (ed.), The Book of Record, a Diary Written by Patrick first Earl of Strathmore and Other Documents Relating to Glamis Castle, 1684-1689, (Edinburgh: Printed at the University Press by T. and A. Constable for the Scottish History Society, 189o), p. 104. 
Jesse mined from the title page of Day's compilations. ${ }^{60}$ While the Tree of Jesse has been altered in its transition to the Hawkings' ceiling, on both the title pages and the ceiling, the bearded patriarch's sleeve identifies him by name.

Day's richly illustrated prayer books also provided the iconography for the 1614 carved overmantel at Postlip Hall in Gloucestershire. ${ }^{61}$ The fireplace overmantel displays an elaborate coat of arms flanked by two psychomachic figures that are nearly identical copies of the personifications of Virtues of 'Temperance' and 'Courage' in the margins of the A Booke of Christian Prayer. The only substantial difference between the two mediums is the omission of the vomit spewing from the figure of 'Intemperance', who lies defeated beneath the feet of 'Temperance'. This tasteful emendation is understandable when one considers that the overmantel is located in Postlip Hall's great chamber, a formal room used for dining in state. ${ }^{62}$ Hamling also found that a composition from Day's prayer books was used in an overmantel in Devon, which copied the illustration of Elijah in the fiery chariot. ${ }^{63}$ In each of these examples, we see not only the internalisation of the Protestant message of Day's images, but also the lasting influence and acceptance of his iconographic program and how it was used by owners in their own pious self-fashioning. Additionally, when transferred into a semi-public space home, the didactic message is opened not just for those who can afford a copy at the bookstall, but to an audience that encompasses every member of early modern households, including servants, apprentices and children.

The illustrations in Christian Prayers and Meditations and A Booke of Christian Prayers resonated for many centuries after they were created. As we saw with these plaster quotations, the iconographic scheme Day established was picked up by others seeking appropriate images. The reuse, copying, exchanging, selling, stealing or recycling of woodcuts and metalcuts was common practice in the early English printed book trade. ${ }^{64}$ This economically

6o Hamling, 'Godly' Household, p. 113. For more examples of printed images used to decorate overmantels, see Anthony Wells-Coles, Art and Decoration in Elizabethan and Jacobean England, The Influence of Continental Prints, 1558-1625 (New Haven: Yale University Press, 1997) and Tara Hamling, 'Guides to Godliness: From Print to Plaster', in Michael Hunter (ed.), Printed Images in Early Modern Britain (Farnham: Ashgate, 2010), pp. 65-85.

61 Hamling, 'Guides to Godliness', p. 70.

62 Hamling, 'Guides to Godliness', p. 70.

63 Hamling, 'Godly' Household, p. 234-235.

64 David J. Davis, 'Images on the Move: The Virgin, the Kalendar of Shepherds, and the Transmission of Woodcuts in Tudor England', Journal of the Early Book Society for the Study of Manuscripts and Printing History, 12 (2009), pp. 99-132; David J. Davis, Seeing Faith; Ruth Luborsky, 'Connections and Disconnections between Images and Texts: The Case of the Secular Tudor Book Illustration', Word and Image, 3 (1987), pp. 74-83. 
prudent practice emerged in response to the limited resources of English book producers, and meant that the iconographic programme that Day established would be seen not only by his own readers, but also by readers of a range of texts for centuries to come. Tracing these transferences allows us to see the reach of a printed image in England and the vast and interconnected network of printers who disseminated them.

In the sixteenth century alone, the images in Day's prayer books were used in ten surviving texts by six different printers. ${ }^{65}$ Some of these diverse works include a Latin grammar by Robert Waldegrave in London, an edition of Bèza's Propositions and Principles of Divinitie also printed by Waldegrave but in Edinburgh, a theological disputation printed in Cambridge by Thomas Thomas and a collection of poems by Giles Fletcher, printed in Cambridge by John Legat. ${ }^{66}$ The same year that construction began on the Hawkings' home, the 1634 edition of Philaster was printed with the Virtue of Patience that had first appeared in the 1578 A Booke of Christian Prayers. ${ }^{67}$ As for the Queen Elizabeth prefatory portrait discussed above, in 1817, Thomas Frognall Dibdin was 'extremely well-persuaded, that this cut of Q. Elizabeth was preserved so late as 1652, and was used in the Benlome's Theophila, [Wing B1879] printed in that year'.68

Certainly, recycling images was common in the English book trade, but the remarkable scale of these repetitions suggests that more than convention was at hand. Whether on a printed page or a plaster ceiling, the images in Christian Prayers and Meditations and A Booke of Christian Prayers had established an iconography free from idolatrous connotations, and was therefore safe for copying. From the reception and repetition of the images, we see that, for the conforming majority, these books offered an approved iconographic scheme to inform, affirm and direct their devotions.

65 Luborsky and Ingram, English Illustrated Books, p. 324.

66 See USTC 510361, 511729, 511100 and 512374. According to McKerrow, by the time of John Day's death in 1584, Richard was already disinherited and did not receive any of his father's printing devices. By 1586, Day's woodcuts and metalcuts can be seen in the works of Waldegrave. Ronald B. McKerrow, Printers' \& Publishers' Devices in England \& Scotland, 1485-1940 (London: Bibliographical Society, 1913), p. 169. He notes that the only major difference is the size of the Virtues, which he ascribes to the shrinking rates of various qualities of metals. Oliver, 'Virtues', p. 310.

67 Francis Beaumont and John Fletcher, Philaster, or love lies a bleeding (London: William Jones for Richard Hawkins, 1634) USTC 3017078.

68 Thomas Frognall Dibdin, The Bibliographical Decameron (London: W. Bulmer \& Co., 1817), p. 114. See sig. Hhir ${ }^{\mathrm{r}}$ of Wing B1879 for the Queen Elizabeth prefatory portrait. 


\section{Conclusion}

Based on the books' unique positions as the only deluxe illustrated prayer books printed during the English Reformation, many scholars have chosen to view Day's works as curiosities or outliers. Similarly, their dependence on books of hours, especially in the border images, has led some to dismiss them as examples of religious continuity. This chapter, by contrast, has contended that, in Day's multifaceted iconographic content, the anxieties that surrounded the use of images in devotions are manifest. As we have seen, tensions about religious images did not just lead to an impulse to destroy; rather, Protestant image creators like Day reshaped, controlled and edited visual content to suit the new religious and political reality. 